\section{Solvent-free enzyme activity: quick, high-yielding mechano- enzymatic hydrolysis of cellulose into glucose}

\author{
Fabien Hammerer, Leigh Loots, Jean-Louis Do, J. \\ P. Daniel Therien, Christopher W. Nickels, \\ Tomislav Friščić* and Karine Auclair*
}

\begin{abstract}
Mechanochemistry enables enzymatic cleavage of cellulose into glucose without bulk solvents, acids, other aggressive reagents or substrate pre-treatment. This clean mechano-enzymatic process is also directly applicable to biomass, avoids many limitations associated with the use of cellulases, and produces glucose concentrations $>3$ times the highest obtained by conventional methods.
\end{abstract}

Cellulose is the most abundant organic polymer on Earth, generated at a rate of $10^{12}$ tons per year ${ }^{[1]}$ and treated mostly as a waste product. It is the strongest contender for replacing petroleum, e.g. in the production of bioethanol or commodity

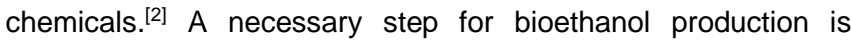
saccharification: breakdown of cellulose into glucose, used as a substrate in microbial fermentation. However, cellulose is a poorly soluble, recalcitrant material, requiring aggressive, toxic reagents, e.g. transition metal ions, ${ }^{[3]}$ strong acids, ${ }^{[4]}$ or hazardous solvents. ${ }^{[5]}$ While such reagents are environmentally taxing and hazardous, they also inhibit yeast fermentation. ${ }^{[6]}$

Cellulolytic enzymes (cellulases) offer a promising approach to cellulose breakdown, but their performance is limited by low conversion rates, and product or substrate inhibition. ${ }^{[7]}$ Current enzymatic processes require chemical pretreatment of cellulose, large volumes of suspensions and related waste management. ${ }^{[8]}$ Attempts to increase substrate loading and reach higher glucose concentrations ${ }^{[9]}$ are challenged by energy needed to stir viscous slurries and the "solids effect": loss of cellulase activity at higher substrate content. ${ }^{[10]}$ The solids effect is explained by mass transfer limitations, and enzyme inhibition by hemicellulose, reaction products, or other compounds. ${ }^{[10]}$ From an evolutionary point of view, the solids effect is unexpected, as most cellulases are excreted by fungi which thrive on the surface of moist lignocellulosic materials, e.g. wood or straw. ${ }^{[11]}$

We now present a route for efficient and selective enzymatic cleavage of cellulose into glucose under

[a] Dr. F. Hammerer, Dr. L. Loots, J.-L. Do, C. W. Nickels, J. P. D. Therien, Prof. T. Friščić, Prof. Dr. K. Auclair Department of Chemistry, McGill University Montreal, Quebec, H3A 0B8 (Canada) E-mail: tomislav.friscic@mcgill.ca, karine.auclair@mcgill.ca

Supporting information for this article is given via a link at the end of the document. mechanochemical conditions, ${ }^{[12]}$ without bulk solvent. Ball milling is known to aid in cellulose amorphization, assisting in subsequent hydrolysis, ${ }^{[13]}$ and mechanochemistry ${ }^{[14]}$ has previously been used for rapid depolymerization of cellulose, using processes relying on continuous mechanical impact and acid impregnation, yielding complex products needing further processing. ${ }^{[15]}$ Enzyme catalysis using mechanochemistry was recognized only recently, by using lipase B from Candida antarctica for kinetic resolution of secondary alcohols, or papain for amide synthesis. ${ }^{[16]}$ By enabling cellulase-catalyzed hydrolysis of cellulose or biomass, without pre-treatment, bulk solvent, acids or transition metals, the herein presented mechano-enzymatic approach is a breakthrough in enzyme catalysis and cellulose saccharification. It demonstrates enzymatic turnover for a highly recalcitrant substrate, and a route to overcome a persistent challenge with cellulase reactions.

We used inexpensive cellulase preparations from Trichoderma reesei, Trichoderma longibrachiatum, and Aspergillus niger, commercially available as lyophilized powders. Microcrystalline cellulose (MCC) was used as a model substrate, as it is more resistant to enzymatic action and chemically welldefined. Cellulases are hydrolytic enzymes; the water content in herein described reactions is given as $\eta,{ }^{[17]}$ the ratio of water volume to the weight of reactants, cellulose and cellulases. For $\eta=0.5-1 \mu \mathrm{L} / \mathrm{mg}$, corresponding to mechanochemical liquidassisted grinding (LAG) conditions that enable reactivity of poorly soluble substances, ${ }^{[16]}$ the reactions were solid mixtures which rapidly turned into thick paste. Cellulose hydrolysis was monitored with 3,5-dinitrosalicylic acid (DNS), which reacts with the reducing end of sugars to afford 3-amino-5-nitrosalicylic acid, ${ }^{[18]}$ allowing the non-discriminate detection of glucose and oligosaccharides. It was used along with thin layer chromatography (TLC) to estimate glucose formation. Percent conversion of MCC was calculated as described in the SI. Unless otherwise noted, all experiments were done in triplicate.

We first explored the activity of cellulases towards MCC without mechanical agitation. Aging of a static mixture of MCC, A. niger cellulases $(0.5 \% \mathrm{w} / \mathrm{w})$ and water $(\eta=0.5 \mu \mathrm{L} / \mathrm{mg})$ at $45^{\circ} \mathrm{C}$ and $100 \%$ relative humidity $(\mathrm{RH})$ for a week ${ }^{[19]}$ gave modest conversion (Fig. S1), improved at higher cellulase loading (Fig S2; enzyme loading is defined in the SI). Highest conversions were observed for $\eta=1 \mu \mathrm{L} / \mathrm{mg}$, with water or aqueous acetate buffer as the liquid phase $(50 \mathrm{mM}, \mathrm{pH} 5.0)$. As previously seen in mechanochemical reactions, ${ }^{[16]} \eta>1 \mu \mathrm{L} / \mathrm{mg}$ was detrimental for reactivity (Fig S3). Analysis of soluble products by TLC revealed mostly glucose, indicating that all three types of cellulase activities: endoglucanase, exoglucanase and $\beta$-glucosidase, are at work (Fig. S4). These results demonstrate that enzymatic digestion of cellulose into glucose is possible without bulk solvent and that excess water can harm the process.

Next, we investigated cellulase activity upon ball milling. After 1 hour of milling in a stainless steel milling jar mounted on a Retsch MM400 mill operating at $30 \mathrm{~Hz}$, a mixture of MCC, $A$. niger cellulases and water $(\eta=0.9 \mu \mathrm{L} / \mathrm{mg})$ gave a $\sim 3-4 \%$ conversion (Table S1). Using a Teflon milling jar improved conversion, likely due sample adhering less to jar walls. ${ }^{[20]}$ Maximum conversion was reached at $\eta \approx 1 \mu \mathrm{L} / \mathrm{mg}$, with water or buffer (Fig. S5). 
Table 1. Performance of different enzyme preparations during milling, or upon aging after milling. Conditions: $200 \mathrm{mg}$ cellulose, $10 \mathrm{mg}$ enzyme preparation $(5 \% \mathrm{w} / \mathrm{w}), 200 \mu \mathrm{L}$ deionized water, milled $30 \mathrm{~min}$ at $30 \mathrm{~Hz}$ in a $10 \mathrm{~mL}$ Teflon jar with $2 \times 7 \mathrm{~mm}$ stainless steel balls, before aging for 1 week at $45{ }^{\circ} \mathrm{C}, 100 \%$ $\mathrm{RH}$.

\begin{tabular}{lcccc}
\hline \multicolumn{1}{c}{ Enzyme origin } & $\begin{array}{c}\text { Protein } \\
\text { content }^{[a]}\end{array}$ & $\begin{array}{c}\text { FPU/g } \\
\text { cellulose }\end{array}$ & milling $^{[\mathrm{b}]}$ & $\begin{array}{c}\text { m Hilling and } \\
\text { aging }{ }^{[\mathrm{c}]}\end{array}$ \\
\hline A. niger & 2 & - -[d] $^{\text {[d }}$ & $3.2 \pm 0.4$ & $11.7 \pm 0.7$ \\
T. reesei & 31 & 16 & $11 \pm 1$ & $23.9 \pm 0.6$ \\
T. longibrachiatum & 12 & 5 & $6.1 \pm 0.6$ & $18 \pm 2$ \\
\hline
\end{tabular}

[a] Measured using the Bradford assay, expressed in \% mass. [b] After the milling phase. [c] After the aging phase. [d] Below the detection limit.

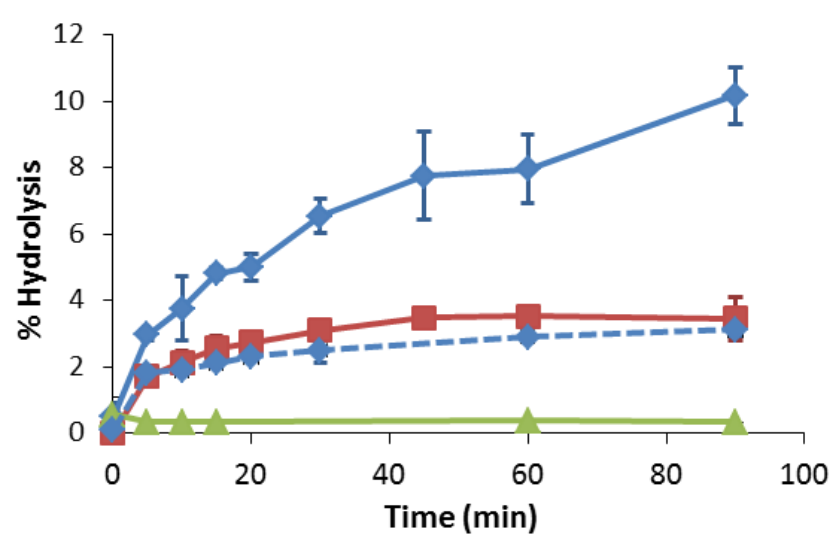

Figure 1. Kinetics of milling reactions using $2 \mathrm{~g} \mathrm{MCC}$ with $100 \mathrm{mg} A$ niger (red) or $T$. reesei (blue) cellulases and $2 \mathrm{~mL}$ deionized water $(\eta=0.95 \mu \mathrm{L} / \mathrm{mg})$. Solid lines are reactions with milling and the broken line is a control reaction without milling. Shown in green is a control experiment without enzyme. Milling was done at $30 \mathrm{~Hz}$ in $20 \mathrm{~mL}$ stainless steel jars with $2 \times 10 \mathrm{~mm}$ diameter stainless steel balls.

Investigating the conversion at milling times of up to 90 min revealed hyperbolic behavior, typical of many enzymatic reactions, for both $A$. niger and $T$. reesei cellulases (Fig. 1). The reduction of reaction rates upon increased milling time is not due to enzyme denaturation, as subsequent aging for a week at $45^{\circ} \mathrm{C}$ led to a further 2- or 3-fold increase in conversion (Table 1) even when milling was performed under harsher conditions, with high-density tungsten carbide balls (Fig. S6). ${ }^{[1]}$ Interestingly, there was no obvious correlation between the in-solution activity (in Filter Paper Units, FPU, defined in the SI) of the three cellulase preparations and the reactivity observed under solventfree conditions (Table 1).

Consistent with the behavior of cellulases in solution, increasing the enzyme loading beyond a certain point, for a constant volume of water additive, did not improve the hydrolysis yield (Fig. S7), a result usually attributed to enzyme overcrowding on cellulose surface. ${ }^{[22]}$ Keeping a constant $\eta=1$ $\mu \mathrm{L} / \mathrm{mg}$ however led to increased conversion even at high enzyme loading ( 46\% after 30 min milling and 1 week aging). Milling was found to favor the formation of glucose and cellobiose, while subsequent aging produced mostly glucose (Fig. S8), suggesting preferential $\beta$-glucosidase activity under static conditions.
Next, we explored a process based on alternating periods of brief milling followed by aging (reactive aging, RAging). Thus $20 \%$ conversion of MCC was obtained after 20 days, by daily milling a mixture containing $5 \% \mathrm{w} / \mathrm{w}$ of $A$. niger enzyme preparation for $5 \mathrm{~min}$, followed by $\sim 24 \mathrm{~h}$ aging (Fig. 2). Exploring the kinetics of milling and of aging (Figs. 1, S9) enabled the technique optimization to 1-hour cycles consisting of $5 \mathrm{~min}$ milling followed by 55 min aging. This was first explored using the $T$. reesei enzyme preparation over 12 cycles, giving $20 \%$ conversion in only 12 hours (Table 2 ). Increasing the aging temperature to $55^{\circ} \mathrm{C}$ or increasing enzyme loading gave moderate or no improvement.

Table 2. Selected RAging results: $200 \mathrm{mg} \mathrm{MCC}$, enzyme (10 or $50 \mathrm{mg}, 5$ or $50 \% \mathrm{w} / \mathrm{w}, 16,25$ or $80 \mathrm{FPU} / \mathrm{g}$ cellulose) and deionized water. Results are shown for 12 cycles of RAging. Milling in each cycle was done for 5 min at 30 $\mathrm{Hz}$ using a $10 \mathrm{~mL}$ Teflon jar with two stainless steel balls of $7 \mathrm{~mm}$ diameter. Aging in each cycle was done for $55 \mathrm{~min}$ at $55^{\circ} \mathrm{C}$, unless otherwise noted.

\begin{tabular}{lccc}
\hline Enzyme source & $\begin{array}{c}\text { Enzyme } \\
\text { Loading }\end{array}$ & $\eta(\mu \mathrm{L} / \mathrm{mg})$ & Conversion (\%) \\
\hline T. reesei $^{[\mathrm{a}]}$ & $16^{[\mathrm{b}]}(5 \%)^{[\mathrm{c}]}$ & 0.5 & $20^{[\mathrm{d}]}$ \\
$T$. reesei & $16(5 \%)$ & 0.5 & $25 \pm 1$ \\
$T$. reesei & $80(25 \%)$ & 0.4 & $26^{[\mathrm{d}]}$ \\
$T$. longibrachiatum & $25(25 \%)$ & 0.4 & $35^{[\mathrm{d}]}$ \\
$T$. longibrachiatum & $25(25 \%)$ & 0.8 & $49 \pm 2$ \\
\hline
\end{tabular}

[a] aging at $45^{\circ} \mathrm{C}$; [b] expressed in FPU/g of MCC; [c] given in weight\%; [d] experiment not performed in duplicate.

Remarkably, T. longibrachiatum cellulases (25 FPU/g MCC or $25 \% \mathrm{w} / \mathrm{w}, \eta=0.8 \mu \mathrm{L} / \mathrm{mg}$ ) gave $50 \%$ conversion in only $12 \mathrm{~h}$ (Table 2). To the best of our knowledge, this is unprecedented for untreated MCC at similar enzyme loadings. Increasing the enzyme loading did not have a significant effect on the yield, while decreasing it below $20 \mathrm{FPU} / \mathrm{g} \mathrm{MCC}$ was detrimental (Fig. S10). Importantly, reactivity did not depend on the jar being closed or exposed to $100 \% \mathrm{RH}$ while aging, suggesting that water accumulation is not a critical factor. Powder X-ray diffraction (PXRD, Fig. S11) on samples after RAging with $T$. reesei enzymes revealed only broad Bragg reflections of residual MCC, indicating that the glucose produced was not crystalline and probably forms a highly concentrated aqueous system. Under the best conditions identified so far, and taking into account the water consumed in the reaction, the final glucose concentration is $\sim 580 \mathrm{~g} / \mathrm{L}$ or $3.2 \mathrm{M}$. This is almost 4 times higher than the highest reported value for a cellulose hydrolysis process (158 g/L or $0.9 \mathrm{M}) .^{[23]}$ Analysis of the MCC residue by atomic force microscopy (AFM, Fig. S12) revealed nano-sized structures characteristic of cellulose nano-crystals (CNCs), recently identified as a high value, renewable product with uses ranging from liquid crystals to therapeutics. ${ }^{[24]}$ 


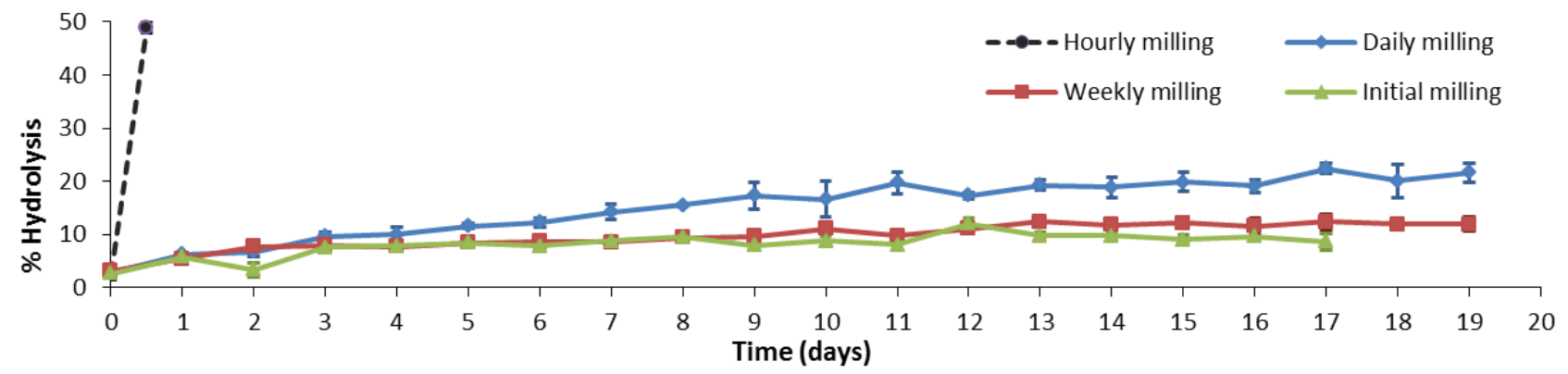

Figure 2. Extent of MCC hydrolysis upon different combinations of milling followed by aging (RAging). Milling was performed: (green) only once; (red) once a week, , (blue) once a day; (black) every hour. Milling was done at $30 \mathrm{~Hz}$ for $5 \mathrm{~min}$, using a stainless steel jar, $2 \times 10 \mathrm{~mm}$ diameter stainless steel balls. Aging was done at $45^{\circ} \mathrm{C}$ and $100 \% \mathrm{RH}$. Reaction mixtures (blue, red, green) were composed of $2 \mathrm{~g} \mathrm{MCC}, 100 \mathrm{mg}(5 \%$ by weight) of $A$. niger cellulase preparation and $2 \mathrm{~mL}$ deionized water $(\eta=1 \mu \mathrm{L} / \mathrm{mg})$ or (black) $200 \mathrm{mg} \mathrm{MCC}, 50 \mathrm{mg}(25 \%$ w/w) of $T$. longibrachiatum cellulase preparation and $200 \mu \mathrm{L}$ deionized water $(\eta=0.8 \mu \mathrm{L} / \mathrm{mg})$.

A preliminary study of scalability was done on a $5 \mathrm{~g}$ model reaction using a planetary mill with $25 \mathrm{FPU}$ of enzyme per gram of MCC $(25 \% \mathrm{w} / \mathrm{w})$ and $\eta=0.75 \mu \mathrm{L} / \mathrm{mg}$ (using water), 10 stainless steel balls of various sizes, in a stainless steel jar $(100 \mathrm{~mL})$. Without optimization, $43 \%$ of the MCC was transformed to glucose over 36 cycles using the T. longibrachiatum preparation.

Finally, we evaluated reactivity of two locally available raw biomass samples, hay and cedar wood saw dust, which were either used untreated or cryo-milled before enzymatic cleavage (Figs 3, S13). At equal enzyme loadings (1\% solid loading $w / v$ in acetate buffer or water, solid loading is defined in the SI), RAging gave higher yields compared to analogous aqueous suspension. This also shows that RAging circumvents the need for biomass pre-treatment, enabling the release of $\sim 1.5 \mathrm{mmol}$ of glucose per gram of biomass without any optimization, a $\sim 3$-fold increase compared to reactivity in aqueous suspension.

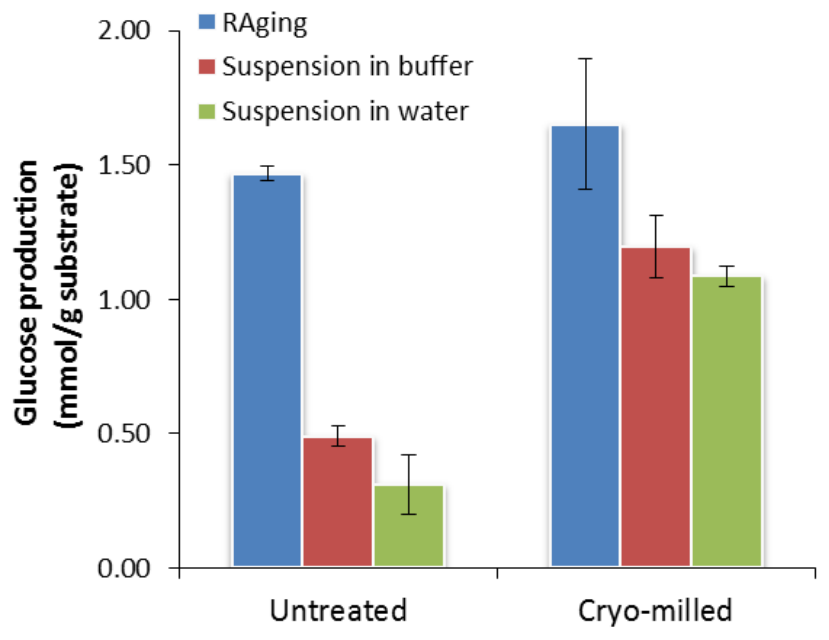

Figure 3. Enzymatic hydrolysis of native or cryo-milled cedar wood saw dust by RAging (blue, $\eta=0.8 \mu \mathrm{L} / \mathrm{mg}$ ) or in $1 \% \mathrm{w} / \mathrm{v}(\eta=100 \mu \mathrm{L} / \mathrm{mg})$ suspension in aqueous buffer (red) or water (green). All reactions lasted $12 \mathrm{~h}$ at enzyme loading of $25 \mathrm{FPU} / \mathrm{g}$ of MCC $(25 \% \mathrm{w} / \mathrm{w})$.

In summary, we demonstrated efficient, clean enzymatic hydrolysis of cellulose into glucose, by switching from conventional solution media to mechanochemistry without bulk solvent. This mechano-enzymatic process has so far enabled unprecedented, direct enzymatic conversion of $50 \%$ of MCC within $12 \mathrm{~h}$. Avoiding the use of bulk solvent enables this process to selectively yield glucose at concentrations $>3$ times larger than those seen in conventional processes, while also producing CNCs, a value-added form of cellulose. This is also a significant improvement compared to enzymatic hydrolysis by milling of cellulose suspensions. ${ }^{[25]}$ While the calculated enzyme productivity of our process $(0.022 \mathrm{~g}$ of glucose/FPU) compares well with that of others (Table S2), the benefits are even more obvious when considering the spacetime yield; at $20 \mathrm{~g}$ of glucose/L/h, this process is at least 20 -fold superior to other reported enzymatic digestions of MCC. Importantly, the process can be applied directly to untreated biomass. Other groups have shown that cellulases can be recycled, ${ }^{[26]}$ and our own preliminary studies indicate that simple centrifugation of the reaction mixture allows direct isolation 
of $>30 \%$ of the glucose produced, and further RAging of the pellet, without adding more enzyme, leads to an additional $20 \%$ conversion of the MCC (Fig. S14). By enabling a high, selective conversion of cellulose directly to glucose, in a surprisingly short time for a cellulase-catalyzed process, and without solvents, acids or transition metals, this approach provides significant advantages over known enzymatic or chemical processes for cellulose breakdown. We are confident that this approach can be further optimized, leading to a paradigm shift in enzymatic transformation of biomass and other recalcitrant substrates.

\section{Acknowledgements}

This work was funded by NSERC DG, CREATE and I2I grants. FRQNT Center in Green Chemistry \& Catalysis is acknowledged for support, CSACS McGill and M. Ramkaran for access to AFM, and Dr. A. Tomberg for cedar wood samples.

Keywords: biocatalysis $\cdot$ cellulase $\cdot$ cellulose $\cdot$ glucose $\cdot$ solvent-free

[1] John Wiley \& Sons Inc, Ed., Kirk-Othmer Encyclopedia of Chemical Technology, John Wiley \& Sons, Inc., Hoboken, NJ, USA, 2000.

[2] (a) Y. Sun, J. Cheng, Bioresour. Technol. 2002, 83, 1; (b) J. J. Bozell, G. R. Petersen Green Chem. 2010, 12, 539; (c) I. Delidovich, K. Leonhard, R. Palkovits Energy Environ. Sci. 2014, 7, 2803; (d) J. Murray, D. King Nature 2012, 481, 433; (e) Q. Xia, Z. Chen. Y. Shao, X. Gong, H. Wang, X. Li, S. F. Parker, X. Han, S. Yang, Y. Wang Nature Commun. 2016, 7,11162.

[3] A. Fukuoka, P. L. Dhepe, Angew. Chem. Int. Ed. 2006, 45, 5161; Angew. Chem. 2006 , 118, 5285.

[4] S. Suganuma, K. Nakajima, M. Kitano, D. Yamaguchi, H. Kato, S. Hayashi, M. Hara, J. Am. Chem. Soc. $2008,130,12787$.

[5] (a) T. Liebert, Cellulose Solvents - Remarkable History, Bright Future 2010, 3; (b) C. Chen, C. Duan, J. Li, Y. Liu, X. Ma, L. Zheng, J. Stavik, Y. Ni BioResources 2016, 11, 5553; (c) N. Sun, H. Rodríguez, M. Rahman, R. D. Rogers Chem. Commun. 2011, 47, 1405. [6]

[6] E. Palmqvist, H. Grage, N. Q. Meinander, B. Hahn-Hägerdal, Biotechnol. Bioeng. 1999, 63, 46; (b) H. B. Klinke, A. B. Thomsen, B. K. Ahring, Appl. Microbiol. Biotechnol. 2004, 66, 10.

[7] S. D. Mansfield, C. Mooney, J. N. Saddler, Biotechnol. Prog. 1999, 15, 804.

[8] N. Mosier, C. Wyman, B. Dale, R. Elander, Y. Y. Lee, M. Holtzapple, M. Ladisch, Bioresour. Technol. 2005, $96,673$.

[9] (a) A. A. Modenbach, S. E. Nokes, Biomass and Bioenergy 2013, 56, 526; (b) R. Koppram, E. Tomás-Pejó, C. Xiros, L. Olsson, Trends Biotechnol. 2014, 32, 46; (c) D. Cannella, H. Jørgensen, Biotechnol. Bioeng. 2014, 111, 59.

[10] (a) J. B. Kristensen, C. Felby, H. Jørgensen, Biotechnol. Biofuels 2009, 2, 11; (b) C. Cara, M. Moya, I. Ballesteros, M. J. Negro, A. Gonzalez, E. Ruiz, Process Biochem. 2007, 42, 1003.

[11] (a) F. Wang, F. Li, G. Chen, W. Liu, Microbiol. Res. 2009, 164, 650; (b) V. Seidl, C. Seibel, C. P. Kubicek, M. Schmoll, Proc. Natl. Acad. Sci. U. S. A. 2009, 106, 13909.

[12] P. Baláž, M. Achimovičová, M. Baláž, P. Billik, Z. Cherkezova-Zheleva, J. M. Criado, F. Delogu, E. Dutková, E. Gaffet, F. J. Gotor, R. Kumar, I. Mitov, T. Rojac, M. Senna, A. Streletskii, K. Wieczorek-Ciurowa, Chem. Soc. Rev. 2013, 42, 7571.

[13] U. Mais, A. R.Esteghlalian, J. N.Saddler, S.D.Mansfield, App. Biochem. Biotechnol. 2002, 98, 815.

[14] S. L. James, C. J. Adams, C. Bolm, D. Braga, P. Collier, T. Friščić, F. Grepioni, K. D. M. Harris, G. Hyett, W. Jones, A. 
Krebs, J. Mack, L. Maini, A. G. Orpen, I. P. Parkin, W. C. Shearouse, J. W. Steed, D. C. Waddell, Chem. Soc. Rev. 2012, $41,413$.

[15] (a) R. Schmidt, S. Fuhrmann, L. Wondraczek, A. Stolle, Powder Technol. 2016, 288, 123; (b) N. Meine, R. Rinaldi, F. Schüth ChemSusChem 2012, 5, 1449; (c) S. M. Hick, C. Griebel, D. T. Restrepo, J. H. Truitt, E. J. Buker, C. Bylda, R. G. Blair Green Chem. 2010, 12, 468; (d) R. G. Blair, K. Chagoya, S. Biltek, S. Jackson, A. Sinclair, A. Taraboletti. D. T. Restrepo Faraday Discuss. 2014, 170, 223.

[16] (a) J. G. Hernández, M. Frings, C. Bolm, 2016, 1769; (b) U. Weißbach, S. Dabral, L. Konnert, C. Bolm, J. G. Hernández Beil. J. Org. Chem. 2017, 13, 1788; (c) M. Pérez-Venegas, G. Reyes-Rangel, A. Neri, J. Escalante, E. Juaristi Beil. J. Org. Chem. 2017, 13, 1728.

[17] T. Friščić, S. L. Childs, S. A. A. Rizvi, W. Jones, CrystEngComm 2009, 11, 418. [18] T. K. Ghose, Pure Appl. Chem. 1987, 59, 257. [19] M. J. Cliffe, C. Mottillo, R. S. Stein, D.-K. Bučar, T. Friščić, Chem. Sci. 2012, 3, 2495.

[20] (a) J.-L. Do, C. Mottillo, D. Tan, V. Štrukil, T. Friščić, J. Am. Chem. Soc. 2015, 137, 2476; (b) B. P. Hutchings, D. E. Crawford, L. Gao, P. Hu, S. L. James, Angew. Chemie Int. Ed. 2017, 56, 15252.

[21] K. S. McKissic, J. T. Caruso, R. G. Blair, J. Mack, Green Chem. 2014, 16, 1628.

[22] K. Igarashi, A. Koivula, M. Wada, S. Kimura, T. Okamoto, T. Ando, M. Samejima, Science 2011, 333, 1279.

[23] X. Zhang, W. Qin, M. G. Paice, J. N. Saddler, Bioresour. Technol. 2009, 100, 5890. [24] (a) C. Salas, T. Nypelö, C. Rodriguez-Abreu, O. Rojas, Curr. Opin. Colloid Interface Sci. 2014, 19, 383; (b) N. Lin, A. Dufresne, Eur. Polym. J. 2014, 59,302

[25] Y. Yu, H. Wu, AIChE J. 2011, 57, 793.

[26] (a) N. Weiss, J. Börjesson, L. S. Pedersen, A. S. Meyer, Biotechnol. Biofuels 2013, 5; (b) E. M. Visser, T. F. Leal, M. N. De Almeida, V. M. Guimarães, Biotechnol. Biofuels 2015, 8, 1; (c) R. Huang, H. Guo, R. Su, W. Qi, Z. He, Biotechnol. Bioeng. 2017, 114, 543. 